\title{
17,18-dihydroxy Montecristin Compound from the Stem Bark of the Soursop (Annona muricata Linn.)
}

\author{
Pince Salempa ${ }^{* 1}$, Muharram ${ }^{\# 2}$, Iwan Dini ${ }^{\# 3}$, Paulina Taba ${ }^{*}$, Asriani Ilyas ${ }^{+}$ \\ ${ }^{\#}$ Chemistry Department, Universitas Negeri Makassar, Makassar, Indonesia \\ E-mail: ${ }^{1}$ pince.salempa57@gmail.com, ${ }^{2}$ muharram_pasma@yahoo.com, ${ }^{3}$ iwandini@yahoo.com \\ *Chemistry Department, Hasanuddin University, Makassar, 90245, Indonesia \\ E-mail: paulinataba@unhas.ac.id \\ ${ }^{+}$Chemistry Department, Universitas Islam Negeri Alauddin, Makassar, Indonesia \\ E-mail: asrianiilyas@uin-alauddin.ac.id
}

\begin{abstract}
The development of natural ingredients use for conventional medicine is now in high requirement due to the traditional drugs are reasonably undemanding to be achieved. Annonaceae is one plant family which is usually utilized as medical plants in Indonesia and many other countries. One species of the family which is regularly used as customary medicine is A. muricata Linn which is well-known as soursop that comes from Caribbean, Central America, and South America. Along with the technological advancement, compounds and efficacy of soursop plant becomes popular. Annona muricata Linn. or soursop belongs to the Annonaceae family that is traditionally used to treat various diseases, such as cancer, diarrhea, convulsive, fungal and itching. The purpose of this study was to isolate and purify secondary metabolites of ethyl acetate fraction of the soursop stem bark. Research methods include extraction (maceration), fractionation and BLST test against Artemia salina. The structure of the 17.18-dihydroxy montecristin compound was determined by IR, $1 \mathrm{H}$ and $13 \mathrm{C}-\mathrm{NMR}$ spectra HMBC and COSY. The compound had an activity to the tumor cell of murine leukemia cells P-388 with the IC50 value of $34.05 \mathrm{mg} / \mathrm{mL}$ respectively. This study found that the compound of 17.18-dihydroxy montecristin have been isolated from the stem bark of $A$. Muricata $L$. which has potential as an anticancer with the IC50 of $34.05 \mu \mathrm{g} / \mathrm{mL}$.
\end{abstract}

Keywords - 17.18-dihydroxy montecistin; soursop; Annona muricata Linn, anticancer.

\section{INTRODUCTION}

The development of the use of natural ingredients for traditional medicine is currently in high demand. This is because traditional drugs are relatively easy to be obtained. Plants can manipulate a wide range of their chemical compounds as a mechanism to maintain their life to the environmental conditions, such as climatic factors, insects, and pests. Plants produce a variety of abundant class of organic compounds where most of the compounds do not appear directly in the growth and development of plants. The plant used as herbal medicines done by people just at the same time people make their civilization and traditional medicines are still crucial for treating by habit. Nowadays, developing countries which has a lack of health services still use folk medicines even without the scientific examination. These chemical substances are simply referred to as secondary metabolites, where their presences are limited to specific species in the plant kingdom. The compounds include alkaloids, acetogenins, and phenolic compounds [1]

Annonaceae is one family of plant that is usually utilized as medicinal plants in various countries including Indonesia. There are 126 genera and 2500 species of the family [2], [3]. One species of the family is often used as traditional medicine is A. muricata Linn known as soursop that comes from Caribbean, Central America, and South America. By the development of technology, compounds and efficacy of soursop plant began to be known. Research on this plant have been done, including the discovery of alkaloids in the leaves and seeds of soursop [4], the content of the antioxidant, anti-inflammatory, antimicrobial, wound healing, antiulcerogenic activity, anti-protozoal, anticancer, insecticides in the ethanol extract of leaves of the soursop [1] , [5]-[11]. Luna et al. [12] reported that the extract of $A$. muricata leaves with polar solvent had the toxicity activity to larvae of the brine shrimp Artemia salina with the LC50 of $0.49 \mu \mathrm{gmL}-1$. Two compounds, murihexocin A and B 
were also isolated from A. muricata leaves showing significant inhibitory effects for tumor cell with selectivity to the prostate (PC-3) and pancreatic (PACA-2) cells [13].

The ethyl acetate extract of $A$. muricata leaves had chemopreventive properties on azoxymethane-induced colonic aberrant crypt foci in rats [14]. It was also reported ethnobotanically that $A$. Muricata had cytotoxic activity [15]. The aqueous leaf extract of this plant has shown hepatoprotective and gastroprotective activities [16]. Antibacterial activities were also reported by several researchers [17-19]. Theoretically, chemical compounds that are bioactive in higher plants can be found in all parts of the plant [20]. Therefore, other classes of compounds such as flavonoids, steroids, and alkaloids can also be found on the bark of A. Muricata L.

Traditionally, the use of $A$. muricata drug has been identified in the tropics to treat various diseases such as fever, pain, respiratory and skin diseases, parasites (internal and external), infections caused by bacteria, hypertension, inflammation, diabetes, and cancer. It has been reported that the plant consisted of more than 200 chemical compounds. The most important are alkaloids, phenols, and acetogenins. Using the vitro study, extracts and phytochemicals from $A$. muricata have been characterized as an antimicrobial, antiinflammatory, anti-protozoal, antioxidants, and insecticides [4].

A. muricata L., also known as soursop is the member of Annonacea that has 130 genera, which leads to 2300 species. Some of them were found in America by the number 51,2 from Africa and one in Asia [7]. The Annonaceae family in Brazil is found to comprise about 29 genera and 260 species found in all natural formations, especially Xylopia, Annona (genus) and Polyalthia (genus input). Only five genera of Annona, Rollinia, Uvaria, Melodorum, and Asimina are known to produce edible fruits, and many of these plants are commonly used in traditional medicine. Annonaceae and all the woody plants of Magnoliales are rich in chemical characteristics and are recognized as terpenoid sources (mainly terpenes), alkaloids (in large quantities, especially isoquinoline derivatives), steroids, polyphenols and flavonoids [21].

People in various parts of the world use soursop leaf ( $A$. muricata Linn) to overcome various diseases. In Haiti, soursop leaves are used to overcome the problem of cough, diarrhea, fever, flu, heart, lactation, fleas, parasites, wounds, seizures, weakness and tranquilizers. In Africa, the leaves are utilized in reducing fever in children. In Brazil, they are used to treat ulcers, bronchitis, heart, diabetes, diarrhea, dysentery, fever, intestinal parasites, wounds, and intestinal worms. In Mexico, they are used to cure diarrhea, dysentery, fever, gum disease and reduce bleeding and in Ecuador, they are used as an analgesic [13].

Central America and South America. Along with the development of technology, content and efficacy of soursop plant began to unfold. Various studies show that the soursop plant contains many properties as medicines. Soursop plant parts, ranging from leaves, flowers, fruits, seeds, root, and bark can be used as a drug. In general, the parts of the soursop plant widely used to treat diseases such as hypertension, diabetes, cough, fever, ulcers, and other diseases [20]. Soursop plants are plants with a variety of health benefits. This plant can be used as a medicine to cure various diseases, ranging from mild illness such as itching of the skin to severe diseases such as tumors and cancer. In addition to cure cancer, soursop fruit also acts as an antibacterial, antifungal effective against various types of parasites/worms. Soursop leaves contain active ingredients, such as saponins, flavonoids, and tannins. As drugs made from plant material, it will be safer if consumed [2].

Compounds on soursop leaves that are suspected to have antidiabetic properties are alkaloid and flavonoid compounds. Flavonoid compounds are present in all parts of plants including leaves, roots, wood, skin, pollen, flowers, fruits, and seeds. Soursop fruit is commonly used to treat diseases caused by worms and parasites, treat fevers, increase milk production in nursing mothers, for diarrhea and dysentery. The crushed seeds can be used as vermifuge and anthelmintic against internal and external parasites and worms [22].

Research on this plant have been done, including the discovery of alkaloids in the leaves and seeds of soursop [23], the content of the antioxidant and anti-inflammatory in the ethanol extract of leaves of the soursop [24]. Compounds of flavonoids were also found in the chloroform extract of meat soursop, and the extract of n-butanol soursop leaves was an active compound that can lower uric acid levels [25]. Flavanoid compounds were also found in the chloroform extract of soursop fruit flesh, and the n-butanol extract of the leaves was an active compound that can lower uric acid levels [3]. The ethanol extract of the leaves produced leucoanthocyanins having nature toxicity to larvae Aedesaegypti. Thus, the extract contained a compound that can be used as a medicine for dengue fever [26]. The methanol extract compounds consisted of kaempferol that is potential as anti-cancer [27]. A previous study on the ethyl acetate fraction of the stem bark of A. Muricata shown that the fraction was active against A. Salina Lach with the LC50 of $16.6 \mathrm{ppm}$ [28-29]. This result indicates that there will be bioactive compounds in the fraction.

Based on the above reason, further research was conducted on the isolation and test of the bioactivity toward murine leukemia cells P-388 of secondary metabolites in the ethyl acetate extract of the bark of the soursop (A. muricata Linn). From the literature search, it was clear that the potential of secondary metabolites found in plants soursop bark can be used as the active compound using a solvent of ethyl acetate.

\section{MATERIALS AND METHOD}

A Fisher John melting point apparatus was used to determine the melting point of the solid compounds obtained from the extract. was determined with. The infrared spectra were obtained with Prestige 21 Shimadzu FTIR spectrophotometer, whereas $1 \mathrm{H}$ NMR spectra and 13C were taken using (500 MHz) and (125 MHz) NMR was obtained by Agilent spectrophotometer using a DD2 console system.

\section{A. Materials}

The material used was the stem bark of A. muricata L., obtained from Pinrang, West Sulawesi. The sample was determined in Herbarium Bogoriene, Biological Research, and Development Center, LIPI Bogor. 


\section{B. Isolation and Purification}

The stem bark of $A$. muricata $L$ was dried under air. The dried stem was cut to small pieces and powdered. The fine powder of A. muricata stems as many as $2.5 \mathrm{kgs}$ was macerated by using methanol as a solvent for $3 \times 24 \mathrm{~h}$. The extract obtained was concentrated by using an evaporator until approximately a quarter of the total volume of the extract left. Furthermore, the concentrated extract obtained was portioned with ethyl acetate using a separation funnel. The filtrate was then evaporated until $15.48 \mathrm{~g}$ of the ethyl acetate extract was obtained. Before fractionation, the extract was firstly analyzed with Thin Layer Chromatography (TLC) and spots obtained were detected by a UV lamp and sprayed with a solution of $1.5 \%$ of cerium sulfate.

In addition, the TLC plate was heated until the spot appears to determine the suitable eluent to be used in fractionation. The ethyl acetate extract consisting of several compounds was fractionated by Vacuum Liquid Column Chromatography using silica gel 60 GF254 Merck 7730 as a stationary phase, and eluent of n-hexane, ethyl acetate : hexane, ethyl acetate, acetone : ethyl acetate, acetone, methanol with the increasing polarity order. The fractionation produced 40 fractions in the TLC plate using the same eluent. Spots with the same an $\mathrm{Rf}$ value were combined until 8 main fractions were obtained $(\mathrm{A}-\mathrm{H})$. All fractions were evaporated until a solid phase was produced.

The main fraction of $\mathrm{D}$ as many as $3.0110 \mathrm{~g}$ was further fractionated by flash column chromatography to separate compounds obtained from Vacuum Liquid Column Chromatography. Eluents used were n-hexane, ethyl acetate: n-hexane, ethyl acetate, and acetone: ethyl acetate, acetone, methanol to produce 20 fractions. Combination fractions obtained and monitored by the TLC produced 8 fractions (D1-D8). The Fraction of D3 was further fractionated by flash column chromatography using eluents with the increase in polarity to produce 23 fractions. After combination, 9 fractions was obtained (D3.1-D3.9). The Fraction of D3.4 was evaporated and a white isolate as many as $0.5769 \mathrm{~g}$ was obtained. The isolate was crystallized and recrystallized to obtain a white crystal as many as $77.1 \mathrm{mg}$. The purity of the isolate was tested by thin layer chromatography using three different eluents; ethyl acetate: acetone (8:2), chloroform: methanol (9:1), and ethyl acetate: methanol $(9: 1)$ to ensure that the compound obtained was pure. The pure isolate had a melting point of $70-72 \mathrm{oC}$, and then identified as compound of 17.18-dihydroxy montecristin.

\section{P-388 Test}

Bioassay using murine leukemia P-388 cells. P-388 cancer is cultured in an RPMI-1640 medium given 5\% calf serum and kanamycin $(100 \mu \mathrm{g} / \mathrm{mL})$. Cells $(3 \times 3$ cells/wells $)$ bred in 96 well plates consisting of 1001 growth mediums per well and incubated at $37 \mathrm{oC}$ in an incubator. Several variations of the compound $(10 \mu \mathrm{L})$ were added to culture on the first day after transplantation. On the third day, $20 \mu \mathrm{l}$ of MTT solution $(5 \mathrm{mg} / \mathrm{mL})$ per well was added to each culture medium. After 4 hours of incubation, $100 \mathrm{~mL}$ of $10 \%$ SDS in $0.01 \mathrm{~N} \mathrm{HCl}$ solution was added to each well and the formazan crystals in each well were dissolved by stirring with a pipette. Afterward, the solution was measured optically densitically using a microplate reader (Tohso MPR-A4i) or ELISA reader at wavelengths of 550 and 700 $\mathrm{nm}$. The experiment was performed with three times of measurement.

The anti-cancer activity was conducted by using murine leukemia cells P-388 as follows: a series of sample concentration was made and put into murine leukemia cells $\mathrm{P}-388$. The cell was incubated for $48 \mathrm{~h}$ and a chromogenic reagent was then added and incubated for $4 \mathrm{~h}$. After addition of a stopping growth reagent, the number of murine leukemia cells P-388 inhibited by the sample was measured by a microplate reader at a wavelength of $540 \mathrm{~nm}$. The IC50 was determined from the data obtained. The compound of 17.18-dihydroxy montecristin had an activity to the tumor cell of murine leukemia cells P-388 with the IC50 value of $34.05 \mathrm{mg} / \mathrm{mL}$.

\section{RESULTS AND DISCUSSION}

The compound of 17.18-dihydroxy montecristin was white-colored powder, with a melting point of $70-72^{\circ} \mathrm{C}$ and weighs $77.1 \mathrm{mg}$. Figure 1 shows the FT-IR of the compound.

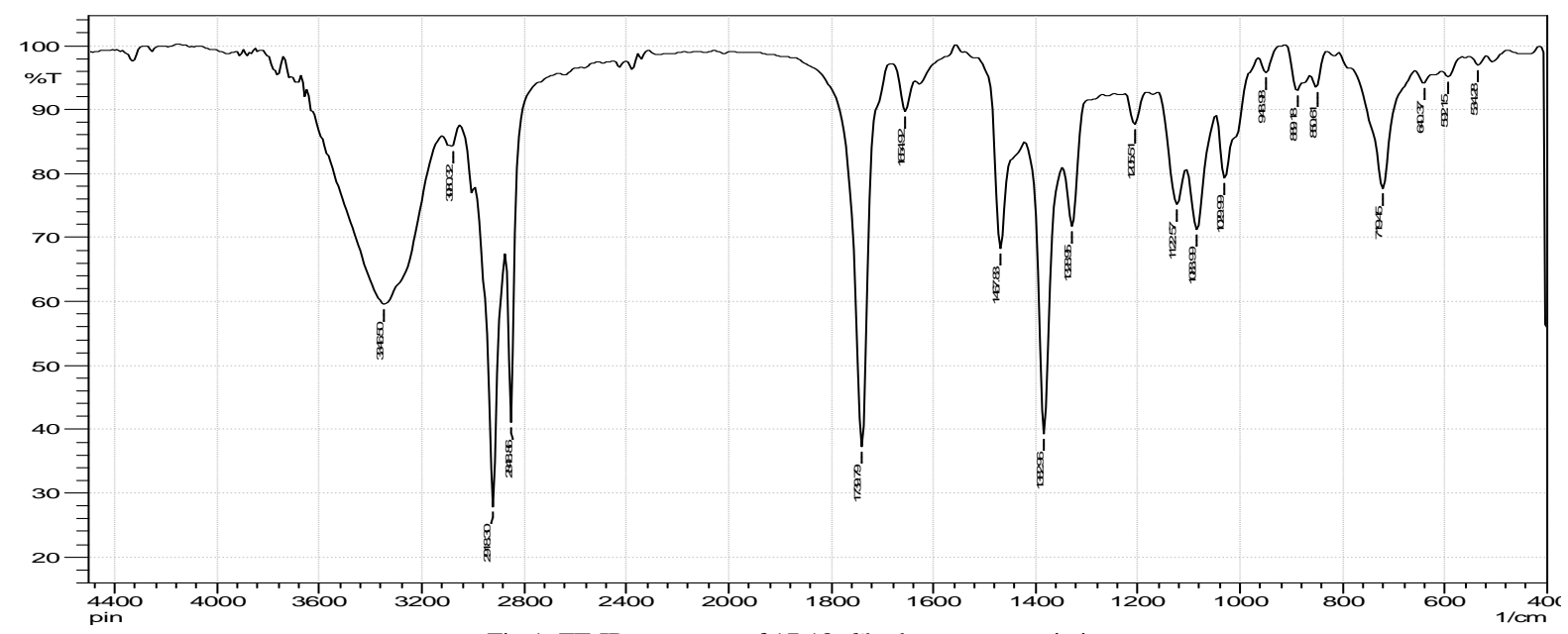

Fig 1. FT-IR spectrum of 17.18-dihydroxy montecristin 
It is clear that there are absorption bands at 3346 and $3080 \mathrm{~cm}-1$ indicating the existence of free $-\mathrm{OH}$ group. This bonding vibration is thought to be the vibration of the $-\mathrm{OH}$ group that is undergoing intermolecular hydrogen bonding, which is supported by the bending vibration at $1070 \mathrm{~cm}-1$ for the stretching vibration of $\mathrm{C}-\mathrm{O}$. Other absorption bands are observed at 2918 and $2848 \mathrm{~cm}-1$ for aliphatic C- $\mathrm{H}$ that supported by bands at $1467 \mathrm{~cm}-1(-\mathrm{CH} 2)$ and $1382 \mathrm{~cm}-1$ (CH3). The absorption bands at $1739 ; 1664 \mathrm{~cm}-1$ belong to the $\mathrm{C}=\mathrm{O}$ group.

Analysis of 1H-NMR spectroscopy data showed typical signals, including 3 proton signals of alkenes at $\delta 7.27 \mathrm{ppm}$ $(\mathrm{H}-35, \mathrm{~d})$ for proton alkene in the cyclic unit, at $\delta 5.41 \mathrm{ppm}$ $(\mathrm{H}-21, \mathrm{~m})$ and $\delta 5.36(\mathrm{H}-22 \mathrm{~m})$ for the proton of the open- chain alkene. The cyclic unit forming the structure of $\gamma$ lactone was shown by the proton signal at $\delta 5.02 \mathrm{ppm}(\mathrm{H}-36$, $\mathrm{m})$ for the proton of methine binding the cyclic oxy group (C-O-). Furthermore, there are 4 signals at $\delta 2.80 \mathrm{ppm}(\mathrm{H}-13$, $\mathrm{m}) ; \delta 2.84 \mathrm{ppm}(\mathrm{H}-14, \mathrm{~m}) ; \delta 3.42 \mathrm{ppm} \quad(\mathrm{H}-17, \mathrm{~m})$; and $\delta$ $3.35 \mathrm{ppm}(\mathrm{H}-18, \mathrm{~m})$ that indicate protons of methine substituted by hydroxyl groups. Two signals at $\delta 0.87 \mathrm{ppm}$ $(\mathrm{H}-34, \mathrm{t})$ and $\delta 1.40 \mathrm{ppm}(\mathrm{H}-37, \mathrm{~d})$ are for methyl protons in the open-chain and bound to the cyclic structure, respectively. Other signals (24 signals) are signals for methylene groups (-CH2-). The proton signals indicate a framework of acetogenin compound (polyketide).

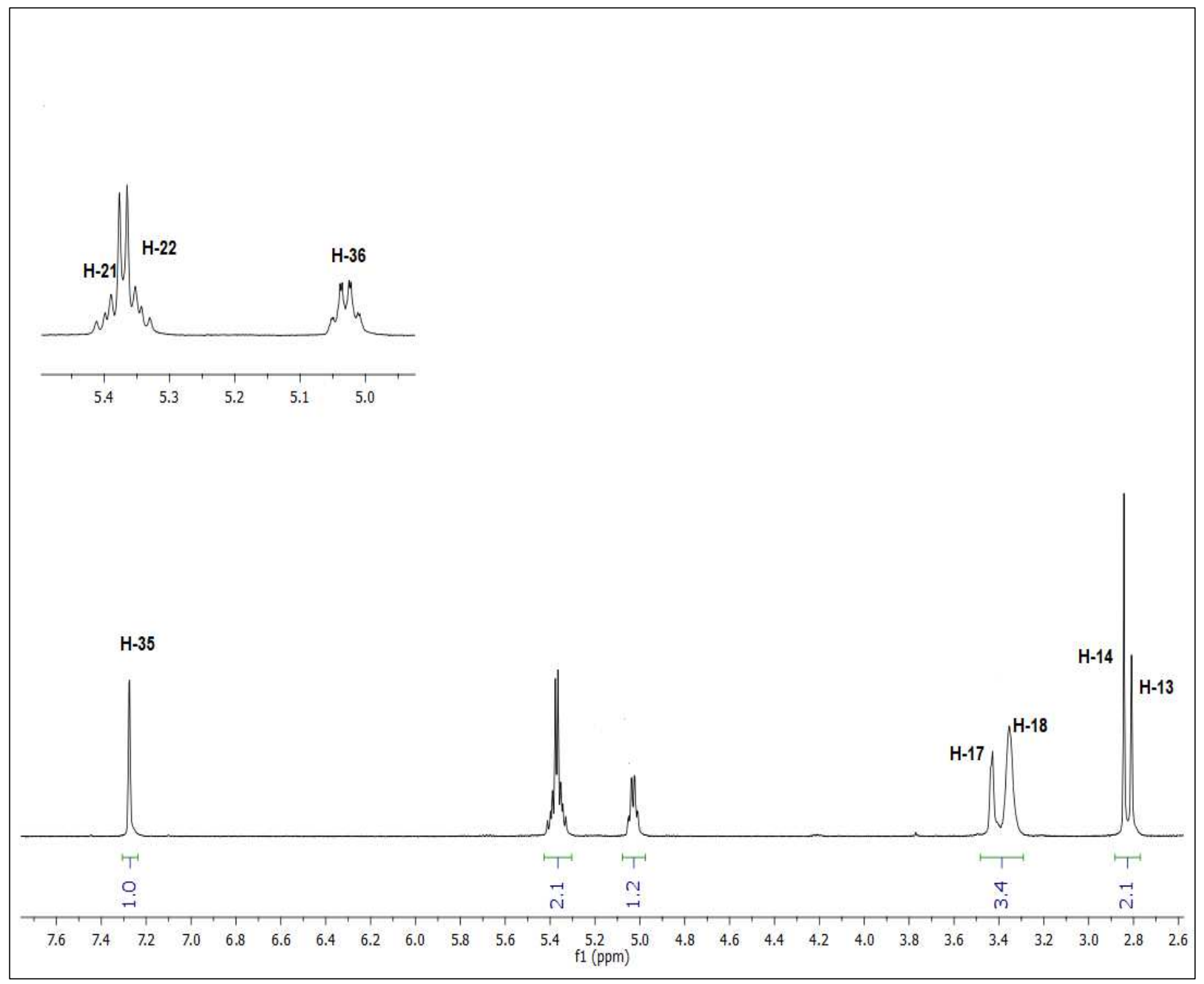

Fig 2. ${ }^{1} \mathrm{H}-\mathrm{NMR}$ spectrum of 17,18-dihydroxy montecristin

Analysis of 13C-NMR spectroscopy data showed 37 carbon signals, which include a carbonyl (C-1) lactone at $\delta$ $173.03 \mathrm{ppm}$; two carbon cyclic alkene at $\delta 133.15 \mathrm{ppm}(\mathrm{C}-2)$ and $\delta 149.88 \mathrm{ppm}(\mathrm{C}-35)$; two open-chain alkene carbon at $\delta$ $129.64 \mathrm{ppm} \quad(\mathrm{C}-21)$ and $\delta 129.78 \mathrm{ppm}(\mathrm{C}-22)$; five oxycarbon at $\delta 77.13 \mathrm{ppm}(\mathrm{C}-36), \delta 73.22 \mathrm{ppm}(\mathrm{C}-13), \delta 73.34$ ppm (C-14), $\delta 73.65$ ppm (C-17) and $\delta 73.75$ ppm (C-18); and two methyl signals at $\delta 13.48 \mathrm{ppm}(\mathrm{C}-34)$ and $\delta 18.57$ (C-37), and 24 signals for methylene (-CH2-) groups.

Bonding relationship structure was proved through a remote correlation of $13 \mathrm{C}-1 \mathrm{H}$ and a spectrum of $\mathrm{HMBC}$ showed the correlation distance between carbon and proton signals, carbonyl carbon at $\delta 173.03 \mathrm{ppm}(\mathrm{C}-1)$ with a proton at $\delta 2.23 \mathrm{ppm}(\mathrm{H}-3) ; \delta 73.22 \mathrm{ppm}(\mathrm{C}-13)$ with $\delta 1.44 \mathrm{ppm}$ (H-12). The complete data can be seen in Table 1. 


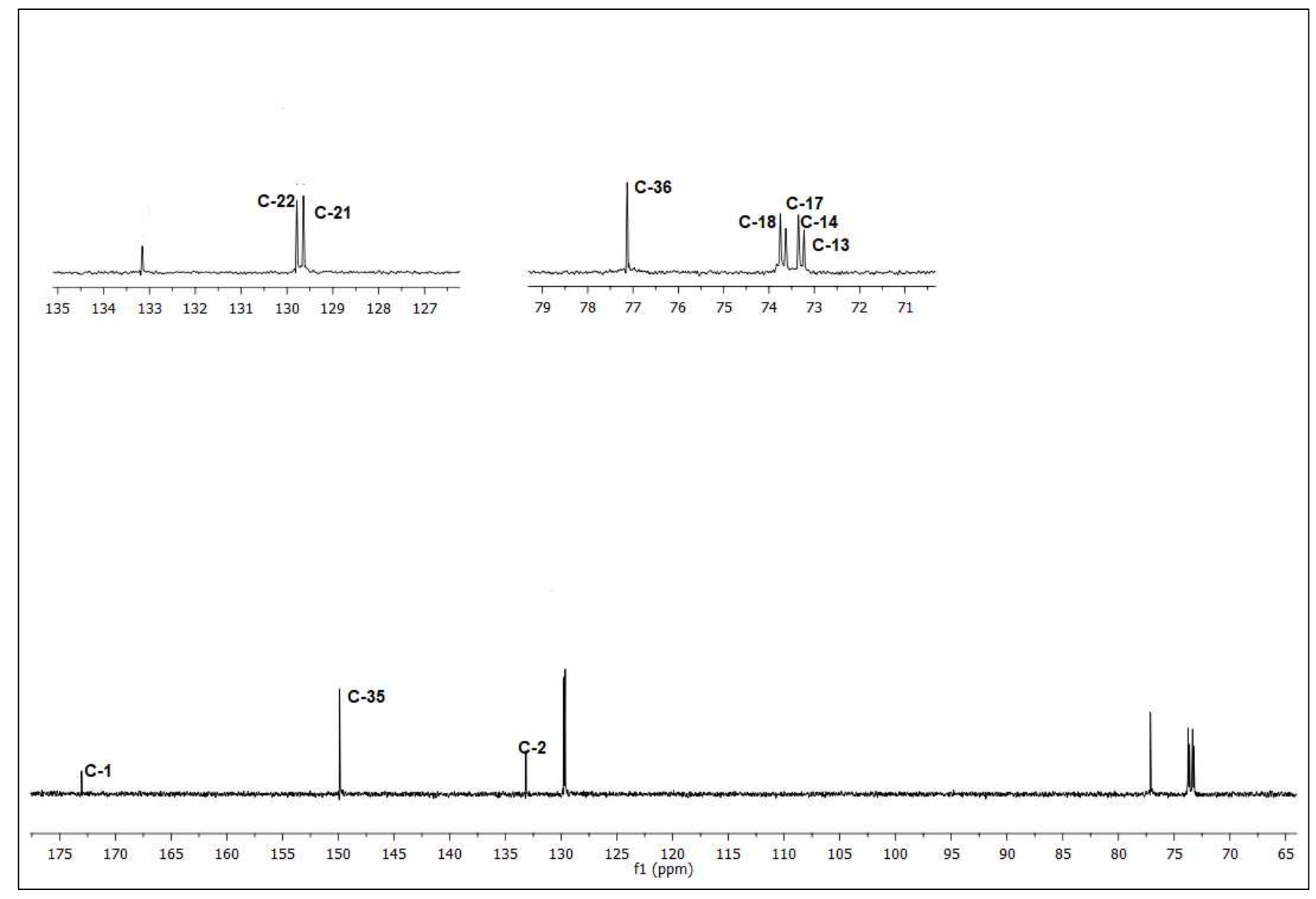

Fig $3 .{ }^{13} \mathrm{C}-\mathrm{NMR}$ spectrum of 17,18 -dihydroxy montecristin

TABLE I

1H, 13C, AND 2D NMR SPECTRUM OF THE COMPOUND

\begin{tabular}{|c|c|c|c|c|}
\hline Atom no. & ${ }^{1} \mathrm{H}-\mathrm{NMR}$ & ${ }^{13} \mathrm{C}-\mathrm{NMR}$ & $\mathrm{HMBC} \rightarrow(\mathrm{CH})$ & COSY (H-H) \\
\hline $\begin{array}{c}1 \\
2 \\
3 \\
4 \\
5-11 / 25-31 \\
12 \\
13 \\
\\
14 \\
15 \\
16 \\
17 \\
18 \\
19 \\
20 \\
21 \\
22 \\
23 \\
24 \\
32 \\
33 \\
34 \\
35 \\
36 \\
37\end{array}$ & $\begin{array}{l}- \\
- \\
2.23(\mathrm{t}) \\
1.55(\mathrm{~m}) \\
1.29-1.38 \\
1.44(\mathrm{~m}) \\
2.80(\mathrm{~m}) \\
\\
2.84(\mathrm{~m}) \\
1.50(\mathrm{~m}) \\
1.50(\mathrm{~m}) \\
3.42(\mathrm{~m}) \\
3.35(\mathrm{~m}) \\
1.56(\mathrm{~m}) \\
2.16(\mathrm{~m}) \\
5.41(\mathrm{~m}) \\
5.36(\mathrm{~m}) \\
2.04(\mathrm{~m}) \\
1.29(\mathrm{~m}) \\
1.29(\mathrm{~m}) \\
1.29(\mathrm{~m}) \\
0.87(\mathrm{t}) \\
7.27(\mathrm{~d}) \\
5.02(\mathrm{~m}) \\
1.40(\mathrm{~d})\end{array}$ & $\begin{array}{l}173.03 \\
133.15 \\
25.75 \\
27.31 \\
22.45-29.65 \\
33.33 \\
73.22 \\
\\
73.34 \\
33.45 \\
33.40 \\
73.65 \\
73.75 \\
33.28 \\
23.44 \\
129.64 \\
129.78 \\
26.89 \\
29.60 \\
31.75 \\
22.45 \\
13.48 \\
149.88 \\
77.13 \\
18.57\end{array}$ & $\begin{array}{l}\text { H-3 } \\
\text { H-3 } \\
\text { H-12, } \\
\text { H }-15 \\
\\
\text { H-23 } \\
\text { H - 34 } \\
\text { H -34 } \\
\text { H -3, H - } 37 \\
\text { H- } 37\end{array}$ & $\begin{array}{l}\mathrm{H}-34 \\
\mathrm{H}-33\end{array}$ \\
\hline
\end{tabular}


Based on data from HMBC correlations, it can be concluded that the compound analyzed was 17,18-dihydroxy montecristin as given in Figure 4.

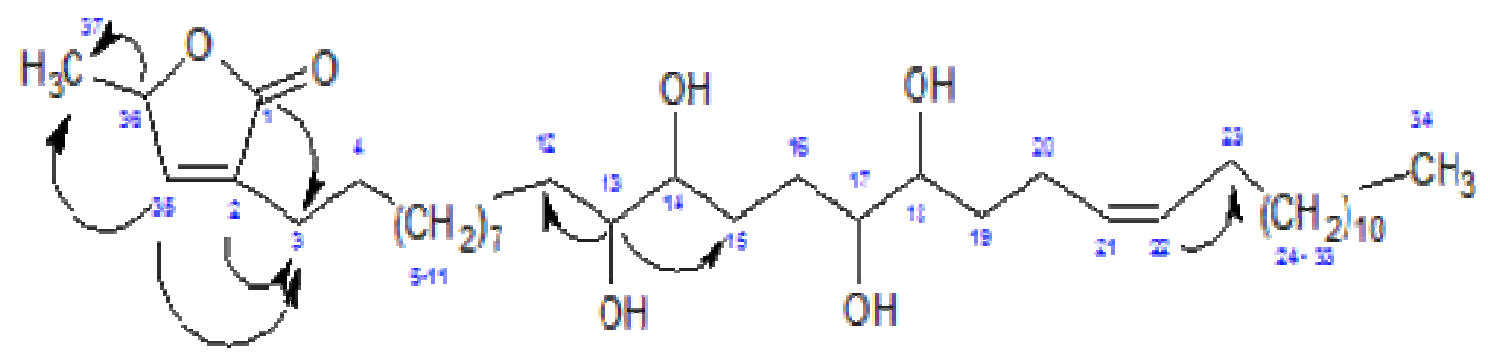

Fig. 4. Compound structure of 17,18-dihydroxy montecristin.

NMR data of 17,18-dihydroxy montecristin compound similar to the derivative compound of montecristin reported previously [12]. The presence of these compounds may be an additional reference in the search for acetogenin compounds in the Annonaceae plant, which may be involved in their biogenesis pathway.

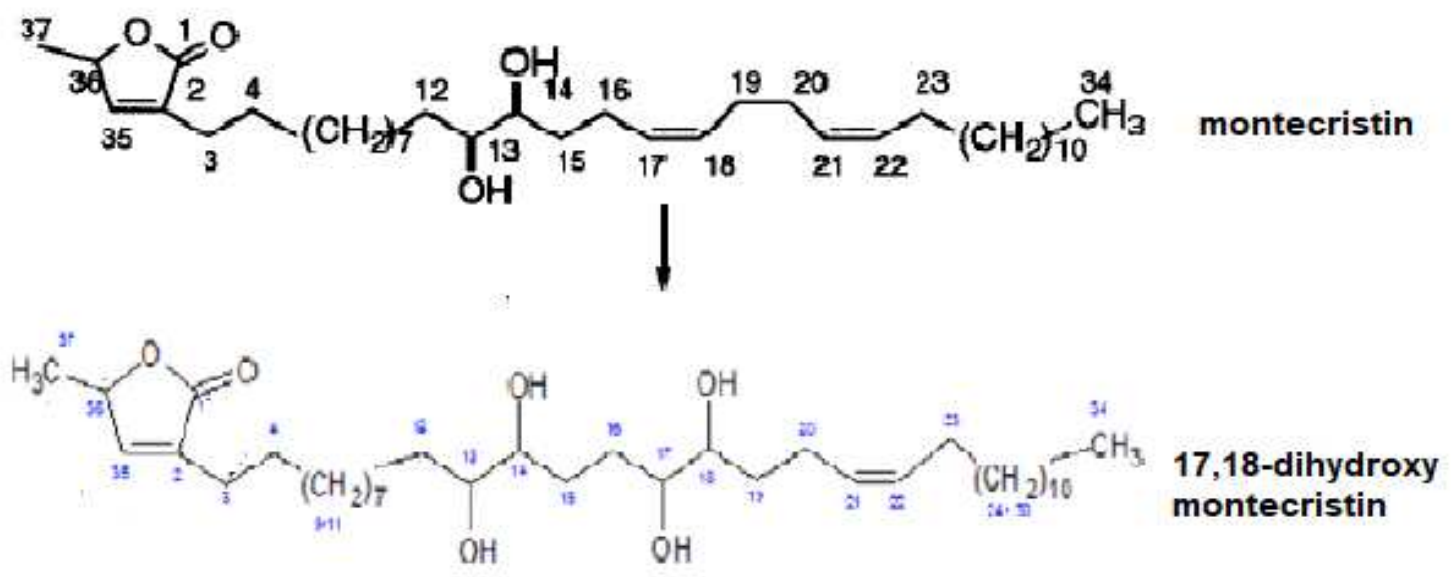

Fig. 5. The structure of montecristin and 17,18-dihydroxy montecristin.

\section{CONCLUSIONS}

The compound of 17,18-dihydroxy montecristin have been isolated from the stem bark of A. Muricata L. The compound is potential as an anticancer with the IC50 of $34.05 \mu \mathrm{g} / \mathrm{mL}$.

\section{ACKNOWLEDGMENT}

Special thank is given to the Ministry of Research, Technology and Higher Education of the Republic of Indonesia for the financial support. Authors would also like to thank the staff Herbarium Bogoriense for the plant identification and to Institute of Technology Bandung for NMR measurement.

\section{REFERENCES}

[1] A. V. Coria-Tèllez, E. M. Gónzalez, E. M. Yahia, and E. N. ObledoVázquez, "Annona muricata: A Comprehensive Review on the Traditional Medicinal Uses, Phytochemical, Pharmacological, Activities, Mechanism of Action and Toxicity", Arab. J. Chem, 2016, http://dx.doi.org/10.1016/j.arabjc.2016.01.004.
[2] Ardraviz. 2012. Khasiat Tanaman Sirsak Untuk Kesehatan. (Online). Available: (http://ardra.biz/kesehatan/khasiat-sirsak).

[3] Artini, N.R., Wahjuni, r., Sulihingtyas, W.D. 2012. Ekstrak Daun Sirsak (Annona muricata L.) Sebagai Antioksidan Pada Penurunan Kadar Asam Urat Tikus Wistar. Jurnal Kimia (ISSN 1907-9850). Vol. 6 No 2.

[4] Ana V. Coria-Te' llez, Efigenia Montalvo-Go'nzalez, Elhadi M. Yahia, Eva N. Obledo-Va'zquez, "Annona muricata: A comprehensive review on its traditional medicinal uses, phytochemicals, pharmacological activities, mechanisms of action and toxicity," Arabian Journal of Chemistry, 2016.

[5] Roduan, M.R.M., Hamid, R.A., Kqueen, C.Y., Mohtarrudin, N., "Cytotoxicity, antitumor-promoting and antioxidant activities of Annona muricata in vitro," J. Herbal. Med., vol. 4, pp. 1-24, 2018.

[6] Minarni, Artika, I.M., Julistiono H., Bermawie N, Riyanti, E.1., Hasim, Hasan, A.E.Z.., "Anticancer activity test of ethyl acetate of endophytic fungi isolated from soursop leaf (Annona muricata L.)," Asian Pac. J. Trop. Med., vol. 10(6), pp. 566-571, Juni. 2017.

[7] Bento, E.B., Junior, F.E.B., de Oliveira, D.R., Fernandes, C.N., de Araujo D.G., Cesario, F.R.A.S., Rodrigues, C.K.S., Sales, V.D.S., de Figueiredo, F.R.S.D.N., Lemos, I.C.S., Monteiro, A.B., de Menezes, I.R.A, da Costa, J.G.M., Kerntopf, M.R., "Antiulcerogenic activity of the hydroalcoholic extract of leaves of Annona muricata Linnaeus in mice," Saudi J. Biol. Sci., vol. 25(4), pp. 609-621, May. 2018.

[8] N.M. Aruan, I. Sriyanti, D. Edikresnha, T. Suciati, M.M. Munir, Khairurrijal, "Polyvinyl alcohol/soursop leaves extract composite 
nanofibers synthesized using electrospinning technique and their potential as an antibacterial wound dressing," in Proc. EPIC, 2016, paper 170 , p. 31-35

[9] Y. Gavamukulya, F. A. Elella, F. Wamunyokoli, H. A. Shemy, "Phytochemical screening, anti-oxidant activity and in vitro anticancer potential of ethanolic and water leaves extracts of Annona muricata (Graviola)," Asian Pac. J. Trop. Med., vol. 7, pp. 355-363, 2014.

[10] S. Z. Moghadamtousi, E. Rouhollahi, M. Hajrezaie, H. Karimian, M. A. Abdulla, H. A. Kadir, "Annona muricata leaves accelerate wound healing in rats via involvement of Hsp70 and antioxidant defense," Int. J. of Surgery., vol. 18, pp. 110-117, 2015.

[11] Nicolas de C.C. Pinto, Lara M. Campos, A. Carolina S. E., Ari S.O. Lemos, Thiago P. Silva, Rossana C.N. Melo, Caroline C. De Lourenco, Marcos J. Salvador, A. Carolina M. A., E. Scio, R. L. Fabri, "Antimicrobial Annona muricata L. (soursop) extract targets the cell membranes of Gram-positive and Gram-negative bacteria," Industrial Crops \& Products., vol. 107, pp. 332-340, 2017.

[12] C. Gleye, A. Laurens, R. Hocquemiller, and A. Cave. Isolation of Montecristin, a key metabolite in biogenesis of Acetogenins from Annonamuricata and Its Structure Elucidation by Using Tandem Mass Spectrometry. J. Org. Chem, 1997.

[13] Duryatmo, S. 2011. Soursop Leaf and Chemotherapy (Thousands Times More Strong). Trubus January 2011.

[14] E. B. Bento, E.F.F. Matias, F. E Brito, D. R. Oliveira, H. D. M. Coutinho, J. G. M., Costa, M. R. Kerntopf, and I. R. Menezes, "Association between food and drugs: the antimicrobial and synergistic activity of Annona muricata L.," Int. J. Food Prop., vol. 16 (4), pp. 738-744, 2013.

[15] F. K. Arthur, E. Woode, E. Terlabi, and C. Larbie, 2011, "Evaluation of acute and subchronic toxicity of Annona muricata (Linn.) Aqueous extract in animals," Eur. J. Exp. Biol. vol. 1, pp. 115-124, 2011.

[16] G. H. Viera, J. A., Mourao, A. M. Angelo, R. A. Costa, and R. H. Vieira, "Antibacterial effect (in vitro) of Moringa oleifera and Annona muricata against gram positive and gram negative bacteria," Revista do Instituto de Medicina Tropical Sa o Paulo, vol. 52, pp. 129-132, 2010.

[17] G. O. Solomon-Wisdom, S. G. Ugoh, and B. Mohammed, "Phytochemical screening and antimicrobial activities of Annona muricata (L.) leaf extract.," Am. J. Biol. Chem. Pharm. Sci., vol. 2, pp. 1-7, 2014.

[18] L. Waston, and M. J. Dalwitz, The Families Of Flowering Plants. http://delta-intkey.com/angio. Accessed on February 20, 2016.

[19] Luna, J. De S., J. M. De Carvalho, M. R. F. De lima, L. W. Bieber, Edson De S. Bento, X. Franck and A. E. G. Sant'ana, "Acetogenins in Annona muricata L. (Annonaceae) Leaves are potent molluscicides," Natural Product Research, vol. 20 (3), pp. 253-257. 2006.
[20] Mardiana, Lina and Juwita Ratnasari. 2012. Herb and Efficacy Soursop. Jakarta: Sower Self Reliance.

[21] Scotti, L., Tavares, J.F., \& da Silva, M.S. 2012. Chemotaxonomy of Three Genera of the Annonaceae Family Using Self-Organizing MAPS and 13C NMR Data of Diterpenes. Quim. Nova

[22] Taylor L. 2002. Technical Data Report for Graviola Annona muricata, 2nd edition. Sage Press: Austin

[23] Wulur, A.C., Identification of Alkaloids on Leaf Soursop (Annonamuricata L.). Manado: Pharmacy Department of Health Polytechnic MoH, 2012.

[24] Suharyadi. 2013. Effect of Ethanol Extract against Soursop Leaf picture Histopathology Kidney Rat DMBA-induced. Journal of Health (ISSN 2337-3776).

[25] Opaladu, N.S. 2013. Isolation and Characterization of Compound Secondary Metabolites of Meat Soursop fruit. Gorontalo: UNG.

[26] Torres, R., Manalo, C.O., Marie, R.Z., Garbo, A.G., "Characterization of the Leaf Extract of Annonamuricata and Larvicidal Activity against Aedesaegypti.Time," Journals of Biological Sciences and Technology, 2014.

[27] Silmi, M. 2011. Potential of kaempferol Soursop Leaves as Inhibitors of Cancer Cell Poliferation Raji. Online. Available: http://repository.ipb.ac.id/handle/ 123456789/56617. Accessed on 20 Februari 2016.

[28] Nahong, C. 2013. Anticancer Activity Of Chemical Constituents Isolated From MiliusaSmithiae. Am. J. App. Sci. (ISSN: 1546-9239).

[29] Simbala, Herny. E,I., "Analisis Senyawa Alkaloid Beberapa Jenis Tumbuhan Obat Sebagai Bahan Aktif Fitofarmaka," Pasific Journal, vol 1, 2009.

[30] P. Salempa, Muharram, I. Dini, "Fractionation Ethyl Acetate Exctract of Stem Bark Soursop (A.muricata Linn)," in Proc. ICMSTEA, 2016, pp. 276-279.

[31] S. Z. Moghadamtousi, M. Fadaeinasab, S. Nikzad, and G. Mohan., "Annona muricata (Annonaceae): a review of its traditional uses, isolated acetogenins and biological activities," Int. J. Mol. Sci., 2015, Available: http://dx.doi.org/10.3390/ijms160715625/.

[32] Suhando, A.K., "Isolasi Terpenoid and Test Antioxidant Skin Stem Extract Soursop (Annonamuricata L.)," Journal of Chemical Unand (ISSN No. 2303-3401), 2013.

[33] V. C. George, D. R. Kumar, V. Rajkumar, P.K. Suresh, and K. Ashok,. "Quantitative assessment of the relative antineoplastic potential of the n-butanolic leaf extract of Annona muricata Linn. In normal and immortalized human cell lines". Asian Pac. J. Cancer Prev. 13, 699-704, 2012.

[34] Zeng, Lu. Feng-E. Wu. Zhe-ming Gu, and Jerry L. McLaughlin. Murihexocins a and b, two novel mono-THF Acetogenins with six hydroxyls, from Annona muricata (Annonaceae). Tetrahedron Letter. $36(30), 5291-5294.1995$. 